\section{APEM}

\title{
A grey-fuzzy approach for optimizing machining parameters and the approach angle in turning AISI 1045 steel
}

\author{
Senthilkumar, N. $^{\mathrm{a},{ }^{*}}$, Sudha, J. ${ }^{\mathrm{b}}$, Muthukumar, $\mathbf{V} .{ }^{\mathrm{c}}$ \\ ${ }^{a}$ Adhiparasakthi Engineering College, Melmaruvathur, Tamil Nadu, India \\ ${ }^{\mathrm{b}}$ College of Engineering, Anna University, Chennai, Tamil Nadu, India \\ 'Saveetha Engineering College, Chennai, Tamil Nadu, India
}

\section{A B S T R A C T}

The influence of the machining parameters and approach angle of carbide inserts over tool wear at the flank face, surface roughness and material removal rate are investigated experimentally in this work. The optimum conditions are found out by using a hybrid grey-fuzzy algorithm. The grey relational analysis and fuzzy logic technique are coupled to obtain a grey-fuzzy grade for evaluating multi-characteristics output from the grey relational coefficient of each response. The experiments were designed using Taguchi's design of experiments; a L9 $\left(3^{4}\right)$ orthogonal array was selected for four parameters varied through three levels. Fuzzy-based reasoning was integrated using the grey approach to reduce the degree of uncertainty. The optimal setting was found out by a response table and the influences of input parameters on the output were determined by Analysis of variance. With the help of this hybrid technique the performance characteristics of the machining process were improved, which is proved by the results from the confirmation experiment.
\end{abstract}

(c) 2015 PEI, University of Maribor. All rights reserved.

\section{ARTICLE INFO}

Keywords:

Machining parameters

Approach angle

Grey relational analysis

Fuzzy logic

ANOVA

*Corresponding author: nsk@adhiparasakthi.in (Senthilkumar, N.)

Article history:

Received 24 November 2014

Revised 7 October 2015

Accepted 15 October 2015 


\section{APEM}

\title{
Sivo-mehki pristop za optimizacijo obdelovalnih parametrov in vstopnega kota pri struženju jekla AISI 1045
}

\author{
Senthilkumar, N. $^{\mathrm{a},{ }^{*}}$, Sudha, J. ${ }^{\mathrm{b}}$, Muthukumar, $\mathbf{V} .{ }^{\mathrm{c}}$ \\ ${ }^{a}$ Adhiparasakthi Engineering College, Melmaruvathur, Tamil Nadu, India \\ ${ }^{\mathrm{b}}$ College of Engineering, Anna University, Chennai, Tamil Nadu, India \\ 'Saveetha Engineering College, Chennai, Tamil Nadu, India
}

\begin{abstract}
POVZETEK
$\mathrm{V}$ članku je raziskan vpliv obdelovalnih parametrov in vstopnega kota karbidnih stružnih ploščic na obrabo orodja na cepilni ploskvi, površinsko hrapavost in stopnjo odvzema materiala. Optimalne obdelovalne razmere smo dosegli z uporabo hibridnega sivo-mehkega algoritma, v katerem smo združili sivo relacijsko analizo in mehko logiko. $\mathrm{S}$ hibridnim pristopom smo ovrednotili izhod, ki ima več značilnosti oziroma izhodnih spremenljivk. Eksperiment je bil načrtovan $\mathrm{v}$ skladu $\mathrm{z}$ Taguchijevo metodo načrtovanja eksperimentov: uporabljena je bila $\mathrm{L}_{9}\left(3^{4}\right)$ ortogonalna matrika, in sicer za štiri parametre in tri nivoje vrednosti. Da bi zmanjšali stopnjo negotovosti smo vgradili sklepalni mehanizem, temelječ na osnovi mehke logike. Optimalne nastavitve smo dobili s pomočjo tabele odzivov. Vpliv vhodnih parametrov na izhod smo določili $\mathrm{z}$ analizo variance. S pomočjo eksperimentov za verificiranje smo potrdili, da hibridni pristop omogoča izboljšavo obdelovalnega postopka.
\end{abstract}

PODATKI O ČLANKU

Ključne besede:

Obdelovalni parametri

Vstopni kot

Siva relacijska analiza

Mehka logika

ANOVA

*Kontaktna oseba:

nsk@adhiparasakthi.in

(Senthilkumar, N.)

Zgodovina članka:

Prejeto 24. novembra 2014

Popravljen 7. oktobra 2015

Sprejet 15. oktobra 2015 


\section{References}

[1] Kalpakjian, S., Schmid, S.R. (2009). Manufacturing Engineering and Technology, $6^{\text {th }}$ edition, Prentice-Hall, USA.

[2] Smith, T.T. (2008). Cutting Tool Technology - Industrial Handbook, Springer-Verlag London Limited, UK.

[3] Tamizharasan, T., Senthilkumar, N. (2012). Analysis of surface roughness and material removal rate in turning using Taguchi's technique, In: Proceedings of IEEE - International Conference on Advances in Engineering, Science and Management, EGS Pillay Engineering College, Nagapattinam, 231-236.

[4] Ramaiah, P.V., Rajesh, N., Reddy, K.D. (2013). Determination of optimum influential parameters in turning of Al6061 using fuzzy logic, International Journal of Innovative Research in Science, Engineering and Technology, Vol. 2, No. 10, 5555-5560.

[5] Hashmi, K., Graham, I.D., Mills, B. (2003). Data selection for turning carbon steel using a fuzzy logic approach, Journal of Materials Processing Technology, Vol. 135, No. 1, 44-58, doi: 10.1016/S0924-0136(02)01011-7.

[6] Cabrera, F.M., Beamud, E., Hanafi, I., Khamlichi, A., Jabbouri, A. (2011). Fuzzy logic-based modeling of surface roughness parameters for CNC turning of PEEK CF30 by TiN-coated cutting tools, Journal of Thermoplastic Composite Materials, Vol. 24, No. 3, 399-413, doi: 10.1177/0892705710391562.

[7] Senthilkumar, N., Tamizharasan, T. (2014). Experimental investigation of cutting zone temperature and flank wear correlation in turning AISI 1045 steel with different tool geometries, Indian Journal of Engineering \& Materials Sciences, Vol. 21, No. 2, 139-148.

[8] Chenna Raidu, C.C., Raghupathy, A.V., Rajasekaran, S., Nayak, P.K. (2010). Fuzzy based cutting data selection for hard turning operation, In: Proceedings of the Frontiers in Automobile and Mechanical Engineering, Chennai, India, 229-234, doi: 10.1109/FAME.2010.5714841.

[9] Kalaichelvi, V., Karthikeyan, R., Sivakumar, D., Srinivasan, V. (2012). Tool Wear Classification Using Fuzzy Logic for Machining of Al/SiC Composite Material, Modeling and Numerical Simulation of Material Science, Vol. 2, 2836, doi: $10.4236 / \mathrm{mnsms.2012.22003.}$

[10] Gupta, A., Singh, H., Aggarwal, A. (2011). Taguchi-fuzzy multi output optimization (MOO) in high speed CNC turning of AISI P-20 tool steel, Expert Systems with Applications, Vol. 38, No. 6, 6822-6828, doi: 10.1016/i.eswa.2010.12.057.

[11] Gokulachandran, J., Mohandas, K. (2012). Application of regression and fuzzy logic method for prediction of tool life, Procedia Engineering, Vol. 38, 3900-3912, doi: 10.1016/i.proeng.2012.06.448.

[12] Senthilkumar, N., Tamizharasan, T., Anandakrishnan, V. (2013). An ANN approach for predicting the cutting inserts performances of different geometries in hard turning, Advances in Production Engineering \& Management, Vol. 8, No. 4, 231-241, doi: 10.14743/apem2013.4.170.

[13] Simunovic, G., Simunovic, K., Saric, T. (2013). Modelling and simulation of surface roughness in face milling, International Journal of Simulation Modelling, Vol. 12, No. 3, 141-153, doi: 10.2507/IJSIMM12(3)1.219.

[14] Rajmohan, T., Palanikumar, K., Prakash, S. (2013) Grey-fuzzy algorithm to optimise machining parameters in drilling of hybrid metal matrix composites, Composites Part B: Engineering, Vol. 50, 297-308, doi: 10.1016/j.compositesb.2013.02.030.

[15] Tamizharasan, T., Senthilkumar, N. (2012). Optimization of cutting insert geometry using DEFORM-3D: Numerical simulation and experimental validation, International Journal of Simulation Modelling, Vol. 11, No. 2, 65-76, doi: 10.2507/IJSIMM11(2)1.200.

[16] Ramamurthy, A., Sivaramakrishnan, R., Venugopal, S., Muthuramalingam, T. (2015). Multi-response optimization of wire-EDM process parameters of titanium alloy using Taguchi method and grey relational analysis, Applied Mechanics and Materials, Vol. 772, 245-249, doi: 10.4028/www.scientific.net/AMM.772.245.

[17] Senthilkumar, N., Tamizharasan, T. (2014). Effect of Tool geometry in turning AISI 1045 steel: Experimental investigation and FEM analysis, Arabian Journal for Science and Engineering, Vol. 39, No. 6, 4963-4975, doi: 10.1007/s13369-014-1054-2.

[18] Taha, Z., Lelana, H.K., Aoyama, H., Ghazilla, R.A.R., Gonzales, J., Sakundarini, N., Sutono, S.B. (2010). Insert geometry effects on surface roughness in turning process of AISI D2 steel, Journal of Zhejiang University Science A, Vol. 11, No. 12, 966-971, doi: 10.1631/jzus.A1001356.

[19] Senthilkumar, N., Tamizharasan, T., Gobikannan, S. (2014). Application of response surface methodology and firefly algorithm for optimizing multiple responses in turning AISI 1045 steel, Arabian Journal for Science and Engineering, Vol. 39, No. 11, 8015-8030, doi: 10.1007/s13369-014-1320-3.

[20] Osorio, J.M.A., Velasco, O.G.D., Rodríguez, C.J.C. (2007). Cutting tool geometry suggestions based on a fuzzy logic model, In: Proceedings of $19^{\text {th }}$ International Congress of Mechanical Engineering, Brasilia, DF.

[21] Singh, D., Rao, V. (2007). Optimization of tool geometry and cutting parameters for hard turning, Materials and Manufacturing Processes, Vol. 22, No. 1, 15-21, doi: 10.1080/10426910601015816.

[22] Senthilkumar, N., Tamizharasan, T., Anandakrishnan, V. (2014). Experimental investigation and performance analysis of cemented carbide inserts of different geometries using Taguchi based grey relational analysis, Measurement, Vol. 58, 520-536, doi: 10.1016/i.measurement.2014.09.025.

[23] Senthilkumar, N., Tamizharasan, T., Anandakrishnan, V. (2014). An hybrid Taguchi-grey relational technique and cuckoo search algorithm for multi-criteria optimization in hard turning of AISI D3 steel, Journal of Advanced Engineering Research, Vol. 1, No. 1, 16-31.

[24] Venkataramaiah, P., DharmaReddy, K., Meramma, P. (2014). Analysis on influence of feed rate and tool geometry on cutting forces in turning using Taguchi method and fuzzy Logic, Procedia Materials Science, Vol. 5, 1692-1701, doi: 10.1016/i.mspro.2014.07.358. 
[25] Senthilkumar, N., Ganapathy, T., Tamizharasan, T. (2014). Optimization of machining and geometrical parameters in turning process using Taguchi method, Australian Journal of Mechanical Engineering, Vol. 12, No. 2, 233246.

[26] Roy, R.K. (2001). Design of experiments using the Taguchi approach: 16 steps to product and process improvement, John Wiley \& Sons, USA.

[27] Ross, P.J. (1996). Taguchi techniques for quality engineering: loss function, orthogonal experiments, parameter and tolerance design, $2^{\text {nd }}$ edition, McGraw-Hill, NewYork.

[28] Senthilkumar, N., Tamizharasan, T. (2012). Impact of interface temperature over flank wear in hard turning using carbide inserts, Procedia Engineering, Vol. 38, 613-621, doi: 10.1016/i.proeng.2012.06.076.

[29] Oberg, E., Jones, F.D., Horton, H.L., Ryffel, H.H. (2008). Machinery's Handbook, 28 th edition, Industrial Press, New York.

[30] Suhail, A.H., Ismail, N., Wong, S.V., Abdul Jalil, N.A. (2012). Surface roughness identification using the grey relational analysis with multiple performance characteristics in turning operations, Arabian Journal for Science and Engineering, Vol. 37, No. 4, 1111-1117, doi: 10.1007/s13369-012-0229-y.

[31] Gopalsamy, B.M., Mondal, B., Ghosh, S. (2009). Optimisation of machining parameters for hard machining: grey relational theory approach and ANOVA, The International Journal of Advanced Manufacturing Technology, Vol. 45, No. 11, 1068-1086, doi: 10.1007/s00170-009-2054-3.

[32] Ahilan, C., Kumanan, S., Sivakumaran, N. (2010). Application of grey based Taguchi method in multi-response optimization of turning process, Advances in Production Engineering \& Management, Vol. 5, No. 3, 171-180.

[33] Klir, G.N., Yuan, B. (1995). Fuzzy sets and fuzzy logic: Theory and applications, Prentice-Hall, USA.

[34] Ross, T.J. (2004). Fuzzy logic with engineering applications, John Wiley \& Sons, UK.

[35] Gamst, G., Meyers, L.S., Guarino, A.J. (2008). Analysis of variance designs - A conceptual and computational approach with SPSS and SAS, Cambridge University Press, Cambridge, UK.

[36] Montgomery, D.C., Runger, G.C. (2011). Applied statistics and probability for engineers, John Wiley \& Sons, Inc., New York, USA.

[37] Lan, T.S. (2011) Fuzzy parametric deduction for material removal rate optimization, Journal of Mathematics and Statistics, Vol. 7, No. 1, 51-56, doi: 10.3844/imssp.2011.51.56.

[38] Shirdar, M.R., Nilashi, M., Bagherifard, K., Ibrahim, O., Izman, S., Moradifard, H., Janahmadi, N., Barisamy, M. (2011). Application of ANFIS system in prediction of machining parameters, Journal of Theoretical and Applied Information Technology, Vol. 33, No. 1, 83-93.

[39] Horng, J.T., Chiang, K.T. (2008). A grey and fuzzy algorithms integrated approach to the optimization of turning Hadfield steel with $\mathrm{Al}_{2} \mathrm{O}_{3}$ /TiC mixed ceramic tool, Journal of Materials Processing Technology, Vol. 207, No. 1-3, 89-97, doi: 10.1016/j.jmatprotec.2007.12.060.

[40] Lian, R.J., Lin, B.F., Huang, J.H. (2005). A grey prediction fuzzy controller for constant cutting force in turning, International Journal of Machine Tools and Manufacture, Vol. 45, No. 9, 1047-1056, doi: 10.1016/i.ijmachtools. 2004.11.023.

[41] Soepangkat, B.O.P., Soesanti, A., Pramujati, B. (2013). The use of Taguchi-grey-fuzzy to optimize performance characteristics in turning of AISI D2, Applied Mechanics and Materials, Vol. 315, 211-215, doi: 10.4028/ www.scientific.net/AMM.315.211.

[42] Rajasekaran, T., Gaitonde, V.N., Davim, J.P. (2013). Fuzzy modeling and analysis on the turning parameters for machining force and specific cutting pressure in CFRP composites, Materials Science Forum, Vol. 76, 77-97, doi: 10.4028/www.scientific.net/MSF.766.77.

[43] Khidhir, B.A., Mohamed, B., Younis, M.A.A. (2010). Modification approach of fuzzy logic model for predicting of cutting force when machining nickel based hastelloy C-276, American journal of engineering and applied sciences, Vol. 3, No. 1, 207-213, doi: 10.3844/ajeassp.2010.207.213. 
[38] Shirdar, M.R., Nilashi, M., Bagherifard, K., Ibrahim, O., Izman, S., Moradifard, H., Janahmadi, N., Barisamy, M. (2011). Application of ANFIS system in prediction of machining parameters, Journal of Theoretical and Applied Information Technology, Vol. 33, No. 1, 83-93.

[39] Horng, J.T., Chiang, K.T. (2008). A grey and fuzzy algorithms integrated approach to the optimization of turning Hadfield steel with $\mathrm{Al}_{2} \mathrm{O}_{3}$ /TiC mixed ceramic tool, Journal of Materials Processing Technology, Vol. 207, No. 1-3, 89-97, doi: 10.1016/j.jmatprotec.2007.12.060.

[40] Lian, R.J., Lin, B.F., Huang, J.H. (2005). A grey prediction fuzzy controller for constant cutting force in turning, International Journal of Machine Tools and Manufacture, Vol. 45, No. 9, 1047-1056, doi: 10.1016/j.ijmachtools. 2004.11.023.

[41] Soepangkat, B.O.P., Soesanti, A., Pramujati, B. (2013). The use of Taguchi-grey-fuzzy to optimize performance characteristics in turning of AISI D2, Applied Mechanics and Materials, Vol. 315, 211-215, doi: 10.4028/ www.scientific.net/AMM.315.211.

[42] Rajasekaran, T., Gaitonde, V.N., Davim, J.P. (2013). Fuzzy modeling and analysis on the turning parameters for machining force and specific cutting pressure in CFRP composites, Materials Science Forum, Vol. 76, 77-97, doi: 10.4028/www.scientific.net/MSF.766.77.

[43] Khidhir, B.A., Mohamed, B., Younis, M.A.A. (2010). Modification approach of fuzzy logic model for predicting of cutting force when machining nickel based hastelloy C-276, American journal of engineering and applied sciences, Vol. 3, No. 1, 207-213, doi: 10.3844/ajeassp.2010.207.213. 